Journal of Law \& Social Studies (JLSS)

Volume 3, Issue 2, pp 113-123

www.advancelrf.org

\title{
An Appraisal of Legal Education: Challenges \& Prospects
}

\author{
Dr. Syed Kaleem Imam \\ $\mathrm{PhD}$ in Politics \& International Relations \\ Federal Secretary, Ministry of Narcotics Control Division. \\ Email:skimam@outlook.com
}

\begin{abstract}
This research is designed to understand the principles of legal education in Pakistan, the existing scenario, and the problems associated with it. It relates future trends needed for the improvement of higher legal education and is an effort to represent the present illustration of legal education in Pakistan and the encountered challenges. It examines the prospects and developments that can be proposed to fortify the essence of this system. Moreover, the predicaments regarding modern legal education and its foundations have been outlined along with proposals for the enhancement in the legal education system that directly influences the quality of to be lawyers. In a nutshell, this article provides explanations to enhance professional capacity in the domain of legal schooling particularly focusing on the context of Pakistan-specific regulatory bodies.
\end{abstract}

Keywords: Development, education, knowledge, lawyer, legal, research, social change

\section{Introduction}

The process of gaining knowledge is defined as education. Education, as a tool and medium, provides the necessary knowledge, insight, and valuable information resulting in skill-based approach, techniques, and understanding of general and specific concepts around the world. Education leads to an expansion in vision and outlook shaping an individual's perception by inculcating capabilities, skills, and a useful lens to analyze situations.

Without the evolution of a nation, development is futile. Evolution, however, is only possible with the right impartment of education leading to the exploration of ideas and concepts. It stresses creativity, which stimulates the human mind to shape individual/group views for the greater good. According to John Dewey (1859 - 1952) known as the father of educational philosophy: Education is a social process; education is growth; Education is not a preparation for life but is life itself.

Knowledge is disseminated through an informal and formal approach. The latter consists of a learning program through a systemic and methodological approach attained through an accepted and recognized curriculum. Topics and subjects have been studied formally in earlier times, but the concept has now been modernized to make technical and social topics accessible (Education around the World).

\begin{tabular}{|l|l|l|}
\hline \multirow{2}{*}{ Definition } & Education & Knowledge \\
\cline { 2 - 3 } & $\begin{array}{l}\text { The enlightenment process of receiving or } \\
\text { giving organized training, especially at formal } \\
\text { platforms e.g. school or university. }\end{array}$ & $\begin{array}{l}\text { Acts, information, and skills gained through } \\
\text { education or practical experience. Knowledge is } \\
\text { the notional or real-world understanding of a } \\
\text { matter. }\end{array}$ \\
\hline Origin & $\begin{array}{l}\text { Acquired through enculturation (cultural } \\
\text { transmission) }\end{array}$ & $\begin{array}{l}\text { Acquired from multiple sources, including but not } \\
\text { limited to perception, reason, memory, testimony, } \\
\text { scientific inquiry, education, and practice }\end{array}$ \\
\hline
\end{tabular}




\section{Legal Education}

Legal education is a branch of mainstream education which deals with the formal study of law. To comprehend the basics of right and wrong, and to fight for rights, one must specialize in law. It is known to be a dynamic subject making it the essence of society's administration and is, therefore, identified as a tool to establish community with pillars of socio-economic justice. Law, as a domain is the regulator of social change and a formal tool for the establishment of a democratic and sustainable community. Legal education is thus the study of the theory of law necessary to acquire as a prerequisite for legal practice.

Law falls under an intellectual arena with specialized concepts and approaches highlighting reasoning where the primary responsibility of legal platforms and associations is to produce social engineers under legal knowledge and rationale. Experts in this domain are aimed to develop and build a socially oriented legal framework to fulfill social, political, and economic uprightness. A socially upright society can be supported only if the legal agenda is integrated in a way that materializes rational and functional methods to address the problems. However, pedagogic skills play a functional role in transforming legal action into a work of art. Its amalgamation is directly affiliated with its delivery.

Law is intended to drive the society forward to reinforce the democratic system and its study is defined as legal education. Formal education in this field consists of promoting notions of research in the legal field and how it could be improved to enhance the law and order in society (Garg, 2020). However, the research should be knowledge-based but at the same time offer a pragmatic approach to acquire the demands.

\section{Purpose of Legal Education}

The development of society, uniformity, and the reinforcement of rule of law depend on the quality and standing of legal education, which is the prerequisite of expert law practitioners. Since the law is defined as the guardian and custodian of social values and personal emancipation, legal education is the tool and medium that allows lawyers to grasp the understanding of the law; holistic and grassroots. This calls for an assessment and revision of the academic curriculum and approaches of law courses to comply with the existing challenges.

Legal education is therefore important to impart the essence of law into the students making them culturally knowledgeable, apt, and committed to catalyzing the cause of justice. High-quality legal education serves as a cornerstone for high-quality legal practitioners resulting in good drafting and advocacy skills. Without the necessary formal legal education, proficient legislators, judges, policymakers, bureaucrats, civil society campaigners, public officials, and responsible citizens is impossible.

\section{Pakistan's Educational Standing}

Pakistan has been given 50 out of 100 points to determine the high school educational system. With a ranking of 9.2, Pakistan is currently lagging due to a weakened system (Pakistan has world's weakest higher education system, say QS rankings, 2016).

Due to the surging population of Pakistan, that young Pakistani lot is expected to increase with the years to come. Pakistan has the highest youth population which is about $64 \%$ under the age of 30 . Despite this, the youth population is under-skilled and under-educated. However, if they are educated and inculcated with the right skills, the growth in economic terms leading to overall modernization would be commendable and amazing.

Pakistan is noted for its increasing unschooled and drop-outs children next to Nigeria. About 22.7 million Pakistani youngsters of age 5 form about from 16 to 44 percent deficient in educational participation as noted in 2017. This is followed by the Gross Enrollment Rate in secondary education which is reaching the lowest threshold of $43 \%$ further plummeting down to $9 \%$ at the tertiary level. This rate is surprisingly low when compared to the international standards.

\section{Pakistan's Existing Education System}

There are two types of education systems that exist in Pakistan. 
1. Pakistan's educational system is categorized into six levels: Preschool, Primary, Middle, High, Secondary School Certificate, Intermediate, Higher Secondary School certificate, university programs leading to undergraduate and graduate degrees.

2. Unconventional modes of diplomas in Pakistan are taken by the British education system, which are now studied in private schools of Pakistan. These modes are acknowledged by other examination boards instead of BISE. General Certificate of Education (or GCE) is the most familiar replacement whereas SSC and HSSC are gradually being replaced by Ordinary Level (or O Level) and Advanced Level (or A Level) respectively (Higher Schooling Certificate).

\section{Adaptation of Single National Curriculum (SNC)}

On the recommendation of the Federal Minister for Education Shafqat Mahmood, a National Curriculum Council was formed in 2018 to remove evident gaps and disparities in the educational system of Pakistan (Omer, 2021). The Single National Curriculum was implemented in 2021 to introduce a universal academic curriculum for private and public institutions.

One system of Education for all, in terms of curriculum, medium of instruction and a common platform of assessment so that all children have a fair and equal opportunity to receive high-quality education (Single National Curriculum).

Principally, the idea behind SNC is to implement "core standards" which will dictate the foundation of the school curriculum.

\section{Legal Education in Pakistan}

The legal system in Pakistan is descended from the English model and was established long before the independence in the 1800s. Through the approval of the laws and structures of British Pakistan, an arrayed legal system grounded on 19th English law was formed. Following this, the first legal establishment came into existence in 1868 by the name of 'University of Law College."

The preceding evaluation reveals that quality assurance for higher education needs strict reinforcement predominantly in legal education. Pakistan, being a developing country needs further upgrading and assurance in terms of quality for long-term improvement in the domain. This indicated that Pakistan is yet to formulate a credible mechanism and means to provide guarantee and reassurance to the public and substantiate with conviction that educational standards are on the track of being progressed.

As for now, Pakistan is facing organizational challenges in the legal educational department which results in fragile governance and administration of law teaching platforms and thus questionable quality of legal education. The legal system in Pakistan needs to be revamped in terms of notable features through which an institute can uphold the standard of education. This can be executed by reviewing the performance indicators, strategic planning, management, administration, and academic audit.

Likewise, accountability, rankings, research capabilities, and teaching methodology should be outlined, signifying a multidimensional approach with all facets in compliance with each other. In a nutshell, Pakistan needs to enrich the valuation of quality by considering students, teachers, faculty, infrastructure, graduate guide services, academic valuation, and scholarship mechanisms, overall.

It is a possibility that legal education in Pakistan is on the decline because of quality compromise and lack of adherence by the regulatory bodies as well as the mechanisms responsible for providing quality assurance. However, since 2015, the legal system in Pakistan experienced a gradual boom making the standards at par with the rest of the countries (Shah, Balasingam, \& Dhanapal, 2018).

To ensure standard legal education quality in Pakistan following steps have been taken in 2015:

1. Introduction of the Pakistan Qualifications Framework,

2. The Higher Education Commission's (HEC) Vision 2025,

3. The new curriculum for Legal Education 
4. The Pakistan Bar Council (PBC) Legal Education Rules.

According to an estimate, 229 universities and colleges are offering LLB Law in Pakistan. These platforms are regulated and monitored by Pakistan Bar Council (PBC) and Higher Education Commission (HEC).

\section{Legal Education Trend in Pakistan}

In Pakistan, the current state of legal education standards is uncertain. The authority has failed to provide the attention it deserved, which has compromised the quality of law graduates. In addition, most of the students lack proper knowledge of the English language, thus creating a barrier in comprehending law-related judgments, approaches, and concepts. Students are not encouraged to work on their judgments, analysis, and ideas and therefore wedged on outdated modes of learning.

There exists a lack of financial rewards and incentives for the faculty as well as the graduates, particularly in public universities. Because of lack of academic pursuits, legal education overall has been compromised, however, the quality is acceptable in private institutions where teachers teach with advanced foreign degrees.

Over the last five years, the five-year BA/LLB program has enrolled most law students. However, this program has failed to accommodate a diverse group of students. The law program is yet to cater to students of different backgrounds which results in an enriched academic experience. Students nowadays can also pursue LLB under the umbrella of London External Programs. This is considered more prestigious than other LLB programs offered by public platforms. However, they are hardly taught about the Pakistani legal system which makes them impractical lawyers (Asad S. I.u.-D., 2009).

Distance learning is unusual in legal education however not unfamiliar. This could also result in a noteworthy influence on citizens' access to legal education and overall services. Likewise, the stimulated learning approach for vocational learning is also spreading across the world and is likely to be prevalent in Pakistan. New forms of pedagogy have a considerable potential to understand the realities of legal practice for new lawyers (Economides, 2015).

Regardless, more and more students are becoming a part of the legal fraternity including women who are becoming increasingly visible, ready to tackle challenges of the traditional system. The numerical presence of students is increasing, which calls for a reformation in teaching methodologies to make students independent.

\section{Law Awarding Universities of Pakistan}

1. There are $\mathbf{4 4}$ Law degree-awarding universities in Pakistan, along with many other affiliated law schools and colleges.

2. Law degree from $\mathbf{2 4 9}$ foreign universities of $\mathbf{3 4}$ countries including, the USA, UK Asian, and commonwealth countries, are recognized in Pakistan.

3. Details of degree-awarding local and foreign recognized universities are mentioned in the First and Second Schedule (Rule-15) of Pakistan Bar Council Legal Education rules 2015.

\section{Ranking of Law Universities in Pakistan - As per (HEC \& Punjab Bar council)}

1- Quaid-i-Azam University, Islamabad

2- International Islamic University, Islamabad

3- Lahore University of Management Sciences, Lahore

4- University of Punjab

5- University of Lahore, Lahore

6- Islamia College University, Peshawar

7- Peshawar University, Peshawar

8- Bahria University, Islamabad 
9- Bahauddin Zakria University, Multan

10- Government College University, Faisalabad

11- Sargodha University, Sargodha

12- University of Sindh

13- University of Gujrat

14- Dadabhoy Institute of Higher Education, Karachi

15- Gomal University, Dera Ismail Khan

\section{Challenges in Legal Education}

\section{Regulatory Bodies}

The impulsive roles by the HEC and the PBC constitutes to lack of quality in legal education. The Pakistan Bar Council Legal Education Rules 2015, which is the legitimate deed for the betterment of advocates fails to address the following:

a. Formulas and techniques to enhance the working of legal education standards and curriculum offered in the LLB program;

b. Familiarization with good quality legal research work;

c. Process of student screening for admission

d. Selecting law graduates possessing appropriate skills and legal aptitude required to elevate legal purview and Pakistani society, by and large

The supervisory bodies, HEC and PBC are responsible to employ a quality assurance framework that lacks a quality curriculum and a discrepancy between general and professional subjects. The PBCLER (Pakistan Bar Council Legal Education Rules) 2015 also fails to address the quality assurance framework and the necessary instructions to follow. The Bar Council should accommodate the quality assurance framework to emphasize quality and development levels. Furthermore, Pakistan Qualification Framework and the LLB (5-year Curricula) by the HEC should also be amended.

\section{Lack of Qualified Teaching Faculty and Adequate Facilities}

Law schools have still not seen a revival and transition from the conventional mode of teaching. No regard is paid to the recommendations consisting of invigorated means of lectures in the academic setting. Most of the law institutes lack permanent faculty members and law experts. The permanent and visiting faculty is hardly evaluated in most public universities.

The teachers are not monitored by the regulatory body and self-assessment is conducted which fails to provide credible recommendations. Due to insufficient pay packages, most law experts are reluctant to join careers as law teachers. The law associations lack facilities such as proper classrooms, lack of research, libraries, unfunded moot courts, and computer labs adding to the downfall of legal education (Chioma, 2021).

Legal education in Pakistan lacks training platforms, absence of quality instructions and occupational workshops. Similarly, the malfunctioning examination system along with lack of supervision and liability adds to the unreliable legal system of the country.

\section{Lack of Legal Vision}

In Pakistan, there is a lack of judicial educational vision and a well-laid out policy. There is an obvious deficiency of coordinated endeavors to training-based assessment, overall legal curriculum, and professional faculty and researchoriented tasks. In addition, Pakistan lacks legal practice as means of progression and innovation, which has created a barrier in maintaining quality legal education. In Pakistan, it is imperative to work on the importance of legal education as an instrument to introduce social justice. 
Furthermore, there is a lack of critical thinking which is the pillar of legal education. Legal classes are conducted without any interactive, one-to-one correspondence policy without the necessary legal drafting words, research skills, writing and negotiations, conflict resolution, and mediation.

In addition, lawyers, firms, and the judiciary are inefficient because of the lack of a practical, theory-oriented approach, and analytical legal image. This further damage the repute as potential lawyers' study legal subjects due to the fear of failing the subjects and enjoying the prestige associated with this profession rather than transforming themselves into excellent law professionals (Edwards, 1997).

\section{Disregarding Technology}

Globalization has conferred us with technology, and it would be beneficial to include advancement in legal practices to produce efficient legal experts. Legal platforms and establishments lack the proper utilization of technological tools such as case management software, research databases, websites, client communication to manage case-sensitive data (Harsh, 2020). Libraries, labs, campuses, auditoriums, and classrooms should be equipped with state-of-the-art technologies to make presentations and dissemination of information prompt and effective.

Research centers should be established to work on in-depth researches on newly founded areas such as intellectual property rights, cyber law, alternative dispute resolution, conflict resolution, transnational human rights, and international business transactions.

\section{Non- Practicing Eligibility Test}

Normally students are enrolled in law colleges without appearing on eligibility tests. The increase in private institutions, admission eligibility, criteria, curriculum development, evaluation and assessment programs, and faulty examination system in teaching procedure adds to the negligent system. Students are not given enough experience in extracurricular activities on legal topics further strengthening their skills. Mock trial and moot courses should be made a compulsory part of the curricular to boost creative and practical skills (Khan, Dastagir, Hak, Hussain, Iqbal, \& Wahab, 2019).

\section{Other Challenges}

a. Experienced faculty hardly remains because of immense salary gaps between law instructors and law professionals

b. Deplorable attitude of law institutes and faculty to just provide degree rather than focusing on acquiring professional knowledge and necessary skills to practice law in the community

c. Academic and legal organizations lack vision to control the mushrooming of inept law schools. The reform process is controlled by working lawyers working with inadequate proficiency to provide legal educational reforms (Arif, Khan, \& Bannian, 2019).

d. Non-compliance of well-designed supervision and monitoring initiatives by the HEC and the PBC;

e. Involvement of academicians in administration and policy making;

f. Improvements in quality assurance benchmark;

g. Legal experts' judgment in planning legal curriculum; and

h. Employment of the laws of governing authorities;

Observation by Supreme Court while perusing Pakistan Bar Council Legal Education Rules 2015: (PLD 2007 SC 394):

"An independent, competent, honest, and industrious judicature required an equally independent dynamic honest, and dedicated bar in order to effectively provide justice in accordance with laws to all members of the society."

The Legal Practitioner and Bar Councils Act of 1973 
The said Act stated standards of expertise required for entry process to the bar. The provisions were regulated by meticulous supervision and enforcement of standards that have been absent in the legal framekwork.

Subsequently, Supreme Court issued some directions as under:

1. Introduction of entrance exam for the bar and law colleges.

2. Ban against law classes by noncertified establishments.

3. Ban on mushroom admissions to post-graduate law programs.

4. Ban on admissions to 3 years LLB program.

5. Ban on holding late classes.

6. Curriculum designation for the LLB programs.

7. Ensuring qualification of faculty members at law colleges.

8. Introduction of distinctive correspondence exam for law progresses derived from overseas universities.

9. Introduction of two weeks training bar vocational course.

10. Allocation of funds in the federal and provincial government.

\section{Career as Lawyer}

A legal system acts as a backbone of every modern civilization to defend civil liberties, interests, life, and property. For smooth functioning of the system, experts who can understand the laws, interpret and explain them to the common people are required to maintain law and order. An advocate speaks to mediate, negotiate and maintain diplomacy on behalf of others in a legal context.

Advocates are licensed to help express facts and opinions allowing them to understand the problems till resolution. They practice law and may be associated with a community volunteer organization, agency, or legal practice to offer help and support. They are provided with the necessary training to represent their clients and discuss legal issues privately.

They are apt in communication, based on research and analytical skills. Moreover, they have an upper hand in representing facts, have a profound understanding of regulations, rulings and statutes to make appeals, contracts, and legal documents (Lawyers: Salary, career path, job outlook, education and more).

\section{Way Forward}

A proper rule of law can be promoted if lawyers are trained properly. The sooner it begins, the more receptive the students will be.

\section{Awareness and Training}

Reforming legal education should be prioritized because lawyers are more prone to an open idea approach and are flexible in their initial stages of studies. Cutting-edge trends should be proposed, and awareness campaign programs should be marketed with academic and practical knowledge simultaneously. Awareness and training should be given to legal academicians and practitioners along with educational sessions for the HEC supervisors and personnel on the mandatory aspects of quality assurance and teaching mechanisms.

A modern and holistic approach along with an exclusive legal study program should be promoted that will generate efficient politicians, judges, legal experts, legal academics, and administration service (Asad \& Petersen, 2019).

Incorporation of bar vocational training course, with detailed coverage of subjects ensuring professional skills, knowledge regarding the procedure, behavioral change, attitude and capacities to become a barrister should be stimulated. Lawyers should be well taught at an academic and vocational level to achieve a period of recognized training (Vocational Component of Bar Training, 2021).

\section{Role of Regulatory Bodies (Pakistan Bar Council and HEC)}


The Pakistan Bar Council needs to execute and implement teaching techniques based on the UK model. As per the UK legal education system, standard codes reflecting quality have been specified with positive and constructive learning and teaching methodology.

Pakistan Bar Council Legal Education Rules (PBCLER) is designed by PBC for proper degree affiliation and recognition of awarding establishment. In 2018, a special committee was formed to monitor the legal education standard of institutions. The PBCLER 2015 however fails to address strategic points as to how to increase the quality standard of legal subjects delivered by local law institutions as part of the LLB curriculum.

High-quality research-based skills should be made part of the pattern, which has not been highlighted under this act. Moreover, it has failed to outline how to produce lawyers with top-notch legal skills that can significantly boost Pakistani administrative society generally and specifically the legal profession. The complete change in Bar Council's outlook needs revolutionization to develop a professional cadre of legal professionals and academicians with the desired know-how.

\section{The National Curriculum Revision Committee (NCRC)}

The National Curriculum Revision Committee (NCRC) should conceptualize in collaboration with the pioneers of the institutions and the PBC legal education board to deliberate for the improvement in legal education. These collaborated recommendations will create an improved curriculum for legal education. Therefore, HEC and PBC should work on quality assurance and endorsement systems as one of the pillars of the bodies (The System of Education in Pakistan, 2006).

HEC should primarily focus on the resolute instructional platform, develop key administrative policies forming itself as a center of quality research and innovation-oriented standard, compacting relations with industry, defining itself as an epitome of enlightenment, instilling technology, and creating influential front-runners (Shah, Balasingam, \& Dhanapal, 2018). HEC initiated performance appraisal standards known as Institutional Performance Evaluation Services launched to enhance the quality. Overall, these two governmental bodies should refine supervision and analysis skills for accreditation processes that are directly responsible for the quality framework.

\section{Modification in Methodology}

The transformation in the pedagogic style of legal education consists of a paradigm shift in contemporary times. Because of the revolution in technology, information, science, communication platforms, and transportation, typical barriers have been eliminated and an integrated and innovative approach for legal studies should be adopted. This calls for a progressive and practical approach because of major phenomenon globalization and liberalization. Prospective lawyers should be exposed to policy formulations and multifaceted approaches of law and order globally.

Moreover, the legal arena should welcome a professional code of conduct, ethics, reformed skills, personal estimations, and behavioral approaches of the lawyers as well as clients. The traditional legal curriculum failed to incorporate new world ideologies and the allowance of competency levels, therefore, rendering it unproductive. Productivity is expected to increase with innovation, to enhance work output leading to value addition into the courses (Garg, 2020).

\section{Introduction of Jurisprudential Ideologies}

Jurisprudence should be taught in high priority within the legal framework. It is defined as the core study of the science of law, consisting of the philosophy of law (Jurisprudence). The essence of law should be refreshed and revitalized with the practice of an analytical and constructive method approach. A comprehensive jurisprudential belief and framework should be exposed to lawyers initiating a system of competency with doctrinal and practical skills.

\section{Strict Monitoring of Eligibility Test and Admission Criteria}

The overall examination critera, which is being implemented by the universities is futile. For the enrolment to Pakistan Bar Council's membership, the examination and eligibility criteria should be revamped. Entrance tests and other eligibility criteria should also be made mandatory. This will verify that LLB applicants have the necessary skillset to appear for the program (Siddique, 2014).

The Supreme Court of Pakistan has commanded to oversee law admission tests by HECP for strict monitoring and evaluation in terms of enrolment in law institutes. The authority has also publicized the outline of eligibility tests to 
determine a student's entitlement for admission in law school through reinforcing assessment of reading, writing, language, general knowledge, and analytical skills.

\section{Program Accreditation and Scrutinization}

The legal frameworks should introduce rigorous monitoring mechanism that reinforces quality standards in legal programs as well as fortify institutional permits and endorsement processes. Law colleges are accredited under The Affiliation Rules of 1998 to control the illegal growth of private law colleges and improve the standard. This has been incorporated into the 2015 amendment, which lays down the minimum criteria for the physical infrastructure, facilities, and administration of law colleges. These prerequisites are not deemed as satisfactory for the establishment, smooth functioning, administration, monitoring, or assessment of law colleges.

There should be a strict check on the qualifications of full and part-time faculty members. The licensing process for accrediting institutions should be reinforced with an external evaluation program consisting of strict, thorough, and transparent screening (Malik, 2016).

\section{Internal and External Audit}

Internal and external audit features should be introduced into the system. This can be materialized with the mutual association of HEC and PBC working towards constant monitoring of the academic organizations, quality declaration worksheet, and supervision of accredited and unrecognized programs along with institutional appraisal that will considerably elevate quality of legal education. Audits of law colleges should be conducted through a neutral party with due representation of the bench and bar (Ranjha, 2018).

\section{Quality Assurance framework}

A comprehensive quality assurance framework should be established by the significant authorities that can analyze and examine the institutions to double-check quality and recognize the flaws of legal education. This framework should be formulated by the Pakistan Bar Council in collaboration with the Higher Education Commission of Pakistan concerning legal education in formal alliance with law academies, colleges and institutes.

\section{Government Introduced Policies}

The creation of a task force was emphasized by the Supreme Court of Pakistan which scrutinized existing gaps and limitations within the legal education system. The task force was visioned to be independent with maximum neutrality and minimum inclination. It was intended to implement, supervise monitorization, and the execution of reforms and recommendations acceptable to the stakeholders.

Such governmental induced platforms should aim towards modifying the minimum standards to handle the license of future lawyers. It should include a change in the minimum hours of pro bono work, a descriptive and verbal re-test of previous knowledge and current skills, etc., and an additional course of reinforcing education before being approved for an advocate license (Malik, 2016).

\section{Quality Assessment}

Academicians and law experts should conduct external inspection to rule out existing flaws in the academic system. This will ensure quality of legal content as well as faculty members, conclusively maintaining educational standard. However, it should be noted that members of the Bar Council are not academicians therefore their presence in analyzing quality assessment for law institutes should be regulated.

The SC, however, has occasionally addressed existing challenges with legal education. In a case titled 'Pakistan Bar Council vs Federal Government of Pakistan', the court acknowledged numerous reasons for the weakening of legal education (Ranjha, 2018).
a. Proliferation of second-rate law colleges;
b. nonexistence of admissibility benchmarks for admission;
c. deprived quality of teaching staff;
d. insufficient resources, services, and substructure; 
e. an inclination for commercial interests rather than academic considerations;

f. lack of thoughtfulness to professional moral code;

g. a substandard exam system.

The Court has delivered significant Judgment for improving standards of legal education in Pakistan (Bar Council vs. The Federal Government \& Others). The Court declared that "sound professional training and skill in both academic and vocational disciplines to essential attributes for ensuring good advocacy" (Arif, Khan, \& Bannian, 2019).

\section{Conclusion}

The legal sector serves as the backbone in strengthening any country empowering social engineers to work together for nation-building. The working of Pakistan's legal education needs serious considerations, which is gradually weakening due to the lack of commitment by universities as well as certified bodies.

There is a lack of well-defined and comprehensive standard policy for law degree curriculum, unconventional teaching modes, examination approaches, and university qualification, which needs attention along with the improper techniques of teaching, nonprofessional ethics, code of conduct, and non-inclination towards academic consideration. Therefore, with the lack of cutting-edge teaching approaches in law foundations and research in the legal sector, the legal education standard has neither escalated in the country nor the research department in the legal sector ever advanced. Consequently, society has failed to discern the value of legal academics and professors.

Pakistan requires legal education that must be socially relevant and justice-oriented which begins by stimulating a change in mindsets and attitudes to launch maximum level of quality in higher education. The path towards the quality improvement of legal education in Pakistan should be multifaceted requiring strong governance. In association with working bodies such as the Task Force, PBC, HEC, and other regulatory authorities in collaboration with abundant resources, restructurings within the system can be acknowledged.

The proposed reforms should aim to progress on commitment, visualization, capital, and motivation. Essential components should be taken from the legal community and law colleges without any compromise. Thus, for success in legal domain, authorities should proceed with critical and positive evaluation to streamline the legal education structure by affiliating it with international benchmarks making it more profitable for the upcoming lawyers.

\section{References}

Arif, D. W., Khan, P. M., \& Bannian, B. (2019). Changing characteristics of Legal Education in Pakistan: Prospects and Challenges. Pakistan Social Sciences Review, 868-880.

Asad, S. I.-u.-D. (2009, December 20). Current Trends in Legal Education. Retrieved 2021, from Dawn: https://www.dawn.com/news/509810/current-trends-in-legal-education

Asad, S. I.-u.-d., \& Petersen, N. (2019, March 25). How to Strengthen Rule of Law Through Legal Education: Lessons from Pakistan. Retrieved November 2021, from Peace Lab: https://peacelab.blog/2019/03/how-tostrengthen-rule-of-law-through-legal-education

Chioma, U. (2021, May 13). Funding, Lack Of Integrity And Inadequate Facilities Are The Major Challenges of Nigerian Legal Education - Law Teachers. Retrieved November 2021, from The Nigerial Lawyer: https://thenigerialawyer.com/funding-lack-of-integrity-and-inadequate-facilities-are-the-major-challengesof-nigerian-legal-education-law-teachers/

Dhall, A. (2014). Legal Education in India: The Emerging Challenges and Prospects. Dehradun Law Review.

Economides, K. (2015). Legal Education.

Education. (n.d.). Retrieved from UNICEF: https://www.unicef.org/pakistan/education

Education around the World. (n.d.). Retrieved from Lumen.

Edwards, H. T. (1997). A NEW VISION FOR THE LEGAL. New York University Law Review.

Garg, N. (2020). Analysis of the Challenges Posed by Legal Education and the Need of Transformation in the Contemporary Times. Nirma University Law Journal, 12.

Harsh, K. (2020, August 11). Technology and Legal Education: Inextricable Entities. Retrieved November 2021, from Legal Bites: https://www.legalbites.in/technology-and-legal-education

Importance of Education in Life. (2018, November 2). Retrieved November 2021, from The Asian School: https://www.theasianschool.net/blog/importance-of-education/

Jurisprudence. (n.d.). Retrieved from Cornell Law School: https://www.law.cornell.edu/wex/jurisprudence 
Khan, H. A., Dastagir, G., Hak, N. A., Hussain, F., Iqbal, M., \& Wahab, a. (2019). Reforming legal education in Pakistan by introducing clinical and practical aspect in the existing syllabus: A key to enhance professionalism within law graduates.

Malik, M. (2016). The State of Legal Education in Pakistan and the Case For Reform in Legal Education. Legal Aid Society.

Ranjha, Z. U. (2018, March 5). Legal Education. Retrieved November 2021, from Dawn: https://www.dawn.com/news/1393268

Shah, S. A., Balasingam, U., \& Dhanapal, S. (2018). Legal Education in Pakistan: An Overview. IIUM Law Journal.

Sherr, A. (2005). Legal Education - Where Do We Begin? Starting Again...Again. Institute of Advanced Legal studies.

Siddique, O. (2014). Legal Education in Pakistan: The Domination of Practitioners and the Critically Endangered Academic. Journal of legal Education.

The System of Education in Pakistan. (2006). Nordic Recognition Information Centres.

Vocational Component of Bar Training. (2021, March 23). Retrieved from Bar Standards Board: https://www.barstandardsboard.org.uk/training-qualification/becoming-a-barrister/vocationalcomponent.html 